\title{
THE RECEPTION OF C.G. JUNG IN US \\ DEATH AND DYING STUDIES
}

JELENA MARTINOVIC

PHANÊS • VOLUME 1 • 2018 • PP. 83-110

https://doi.org/10.32724/phanes.2018.Martinovic 


\begin{abstract}
C.G. Jung's work has had a noticeable impact on conceptions about death and the dying experience, as well as on the therapeutic work methods that deal with anxiety, depression or terminal illnesses. This article analyses the reception of C.G. Jung's work in the United States during the time period 1960-80. It examines ways in which Jung's concepts were discussed and applied by psy practitioners who worked in fields related to death and dying studies (thanatology, palliative care, suicide and neardeath studies). Following an examination of Jung's 'Americanisation' in the 1950s and the reception of his commentaries on death, discussed in relation to the reception of The Tibetan Book of the Dead, I will analyse four examples: 1) a psychiatric interpretation of Jung's account of a neardeath experience and its comparison with William James' mystical states of consciousness; 2) psychedelic therapies conducted with LSD, in which 'symbolic dying processes' are provoked; 3) suicide studies done on suicide survivors; 4) parapsychological investigation of near-death experience. The examples show that Jung's work was pivotal, allowing psychologists to link it to concepts and approaches to terminal illness and positive or transpersonal psychology. Within the period under consideration, Jung's reception has to be read and understood in relation to the more general reception of James' work, in particular his psychology of religion.
\end{abstract}

\title{
KEYWORDS
}

William James, near-death experience, thanatology, palliative care, Tibetan Book of the Dead, LSD therapy, suicide studies, humanistic psychology 
$\mathrm{I}$ t has been widely acknowledged that Carl Gustav Jung made an important contribution to the psychological study of death. Jung's commentary on the Bardo Tödöl and his questioning of immortality tend to be highlighted in this regard. Historians have also emphasized the central role that Jung played in the development of the psychology of religion in the West (Wulff 1991). Less has been written about Jung's influence on the development of death and dying studies in North America subsequent to his own death in 1961.

The mid-twentieth century was a decisive moment for both the reception of Jung and the history of psychological sciences. As Jung scholars have shown, the 'Americanisation of Jungian ideas' is crucial for the understanding of the intellectual history and legacy of Jung. ${ }^{1}$ Since the turn of the century, American scholars and practitioners played a major role in promoting and remodeling Jungian ideas. Pioneering psychotherapists, especially in New England, applied Jung's ideas in psychotherapy to value the 'actualization of personal potential' (Taylor 1998, 100). Here, I will focus on the reception of Jungian ideas in humanistic and transpersonal psychologies. These emerging fields of research and therapy linked Jung's ideas to the study of cultural, existential or spiritual attitudes towards death. Hence, in what follows, I examine a specific episode of Jung's legacy in the United States, in the context of 'death and dying studies'. For the purpose of this article, I use 'death and dying studies' to designate a series of intellectual and clinical practices developed in the 195070 s, which addressed death in mental health prevention and treatment, within the context of the creation of palliative care and thanatology. ${ }^{2}$

It is no coincidence that Jung's popular success in the United States developed at the same time as the death and dying studies. The latter evolved out of an intellectual debate in which psychodynamic interpretations were predominant. For instance, concepts such as the 'taboo' or 'denial of death' were promoted (Feifel 1959) to criticise the advances of biomedical sciences and emergency care technologies, which were considered responsible for pushing the experience of dying to the background. In this period, designated retrospectively as the 'rediscovery of death' (Vovelle 1980), psychologists and psychiatrists strongly shaped a psychological definition of death (Martinovic 2017). Drawing on humanist teachings on the art of dying, theories of grief and trauma, but

\footnotetext{
1 See Eugene Taylor's foreword in Psychology of the Unconscious (Jung 1991).

2 I use the term 'death and dying' also specifically in reference to Elisabeth KüblerRoss' influential book, published with this same title in 1969 (Kübler-Ross 1969). See also (Martinovic 2017).
} 
also mysticism and the work of Jung, these psy practitioners promoted the meaningfulness of dying in clinical research, palliative care and the medical humanities. ${ }^{3}$ The rise of death and dying studies in the late 1950 s subsequently led to the emergence of scholarly work on neardeath experiences and psychotherapeutic methods 'mimicking' death-like encounters. The examination of these developments, which began in the late 1960s, enables us to reflect on Jung's influence beyond his immediate circle of followers and in the era generally characterised as Post-Jungian. It furthermore enables us to detect how, and to what extent, Jung's commentaries on death — in particular his foreword to the Bardo Tödöl and his own account about a near-death experience_—offered key elements for practitioners to rethink and redesign existing models in psychotherapy, such as the treatment of patients suffering from depression and incurableillnesses.

\section{THE 'AMERICANISATION' OF JUNG}

Jung's reception in the United States has been growing since his first visit to Northern America in 1909 (Taylor 1986; Taylor 1998). In fact, Jung's affinities with Anglo-American physicians and patients developed already in 1900, at the Burghölzli Clinic (McGuire 1995), which successively led to editorial collaborations, financial support and the establishment of Analytic Clubs. The translation of Wandlungen und Symbole in 1916 by Beatrice M. Hinkle (Jung 1991) marked an important moment in the distribution of Jung's work. If the first decades of the twentieth century can be characterised by personal relationships that Jung maintained with Northern American analytic therapists and Analytic Club founders, the 1950s introduced a shift of attention in the reception of Jung's ideas, especially in humanistic psychology. There, Jung's ideas were considerably reshuffled. Abraham Maslow, for example, puts forward the importance of Jung's contribution for liberating the notion of unconscious from Freud's theoretical framework, and allowing its comparison with other fields of study, such as Zen Buddhism (Maslow 1976:490-491). Most importantly, Jung's conception of personality was regarded as paramount in these circles. It presented a historical precursor to the humanist ideals spreading in the US from the

\footnotetext{
3 The Medical humanities was officially promoted from 1969 on by the Society for Health and Human Values to commit clinicians to scholarship and teaching in the humanities (Charon and Williams 1995).
} 
1950s onward. Alongside Carl Rogers, Karl Abraham, Gordon Allport, Kurt Goldstein and Jean-Paul Sartre, Jung was included, with his text 'The Development of Personality', in the seminal book Self: Exploration in Personal Growth published in 1956. The editor, Clark E. Moustakas, introduced Jung as someone who 'continues to present his unique ideas in personality and their relevance to a world-view' (Moustakas 1956).

What kind of world-view was Moustakas referring to? In other words, what was the $1950 \mathrm{~s}$ perspective on psychology in the United States, and its contribution to the world?

Post-World War II social sciences have been qualified by historians as a period in which theories on the 'democratic', 'non-authoritarian' or 'open mind' proliferated with regards to personality and its place in culture (Cohen-Cole 2014). Émigré German-speaking analysts, psychologists and sociologists played a considerable role in this development, as they reexamined the relationship between the individual and the collective with regard to political and economic dynamics. The works of Erich Fromm and Theodor Adorno are standard in this regard. At a time when psychology was considered an all-encompassing science that penetrated into the many aspects of daily life, social scientists, including psychologists, explained emotional distress increasingly with the industrial and societal developments of the Western industrial world (Burston 1991). Promoting a collective Sane Society (Fromm 1955), psychologists-who were often thinking more in terms of anthropologists and sociologists than clinicians — were part of a broader turn, initiated after World-War II, that brought the prevention of mental health into the centre of attention.

Jung's oeuvre was received within this context that favoured mental health rather than mental illness. For instance, his conception of the psyche as a 'historical structure' that changes over the course of a life-time (Jung in Perry, 1953:vi) strongly connected to humanist psychology and its conception of personality. In his influential book Becoming, Gordon Allport referred to Jung to make the argument that 'personality is not what one has, but rather the projected outcome of his [the individual's] growth' (Allport 1955:90). Jung's work also influenced those who were engaged in a non-pathological approach for the treatment of mental illness. John Perry (1914-1998), who would become the creator of Diabasis (a residential facility for adults suffering from psychosis and who were treated without medication) was granted a preface by Jung in his book The Self in the Psychotic Process published in 1953. There, Jung establishes his legacy as a forerunner of non-pathological conceptions of mental illness. For instance, Jung claims in this preface that very early on 
in his career he had a strong reaction when he heard the medical 'axiom,' 'mental diseases are diseases of the brain' (Jung 1953, in Perry: v). ${ }^{4}$

Jung cannot beequated with humanistic psychologists orpsychologists who were inclined towards critical cultural analysis. Rather, the Swiss analyst was emphasising the value of symbols, the archetype or collective unconscious more so than societal, economic or political structures as the driving forces in personal growth. But, more broadly, his reception in PostWorld War II America opened up questions on some urgent matters, such as the relationship between insanity and sanity; medicine and spirituality; living and dying. With regards to Jung's 'Americanisation' in the context of death and dying studies, it is interesting to highlight that Jung's paper on 'Seele und Tod' (1934) has first been published (and translated by R.F. C. Hull) in The Meaning of Death (Feifel 1959) before it was integrated in the volume 8 of 1960 Jung's Collected Works. Herman Feifel's 1959 book was seminal: it popularised the study of attitudes towards dying both among psychologists and the general public. Jung's 'The Soul and Death' was thus chosen as the opening article of the book, introducing the first chapter, 'Theoretical Outlooks on Death'. The editor of the book presents Jung as the one who stresses 'the point that the rationalistic view of death tends to isolate man further from his psychological self and underlines the need for psychology to digest certain parapsychological findings' (Feifel 1959: xii). Gardner Murphy, a psychologist and parapsychologist, who contributes with a paper to The Meaning of Death, highlights also Jung's importance for the discussion of parapsychology, while also cricitising Jung's generalisation about 'the first and last halves of life' (Gardner 1959:319).

From the mid-twentieth century on, and especially in the context of increasing interest in the meaningfulness of dying, Jung offered psy practitioners a way to address key issues, when medical science was short of evidence. But, his work also allowed some practitioners to connect experimental psychology to a philosophy of mysticism, as we will see in the following section. To discuss this, let me first start with Jung's commentary on death, paying particular attention to The Tibetan Book of the Dead.

\section{RE-SITUATING THE TIBETAN BOOK OF THE DEAD}

Jung wrote extensively on death-related issues: 'Seven Sermons to the Dead' (1916); 'Commentary on the Secret Golden Flower: A Chinese Book

\footnotetext{
4 This was first quoted in The Content of the Psychoses (Schriften zur angewandten Seelenkunde, 1907).
} 
of Life' (1925); 'Marriage as a Psychological Relationship' (1925); 'The soul and death' (1934); 'Concerning Rebirth' (1939); 'The Psychology of Transference' (1946) (Yates 1999; Shamdasani 2008). Jung also developed his own makings of a theology of the dead in the Red Book, which included as well the privately published 'Seven Sermons' (Shamdasani 2009). Yet, two publications stand out with regard to Jung's legacy in death and dying studies in the United States. First, his commentary on Das Tibetanische Totenbuch, initially published by Rascher Verlag in 1935, which was translated by R.F.C. Hull with the help of James Kirsch and included in the third edition of W. Y. Evans-Wentz influential The Tibetan Book of the Dead in 1957; second, his description of his near-death experience, which was included in Memories, Dreams and Reflections, published the following year after its German release in 1962. Jung's commentary on The Tibetan Book of the Dead was an important moment. It resituated Jung's contribution to psychology at the intersection of 'ars moriendi' and Oriental philosophies. Both came to shape psychotherapy in the 1960-70s.

To illustrate this, let me comment on the English-language editing history of The Tibetan Book of the Dead. First published in English in 1927 by Oxford University Press, The Tibetan Book of the Dead, a manual for the intermediate state between life and death (Bardo), was subsequently re-edited by Evans-Wentz in 1949 and 1957. A comparison of the three editions gives significant insight into how death and dying was brought to the attention of English-speaking readers. In 1927, the editor claimed that he was acting 'simply as the mouthpiece of a Tibetan sage, ${ }^{5}$ while also pursuing the aim to 'reproduce Oriental ideas in a form which would be intelligible for the European mind' (Evans-Wentz 1949:xvi). The second edition more directly links the importance of the Bardo Tödöl to different traditions of the 'art of dying'. Most importantly, Evans-Wentz establishes a comparison with the Egyptian Book of the Dead. The latter was an English reformulation of its original meaning, The Coming Forth from Day. Equally, Bardo Tödöl initially means, in transliterated Tibetan, 'Liberation in the Intermediate State through Hearing' (Lopez 2011:2). Evans-Wentz deliberately chose Book of the Dead to cross-reference the meaning of Tibetan Buddhism teachings on death with the Egyptian Book of the Dead. This was a way for the author to establish the two manuals as the main

\footnotetext{
5 Evans-Wentz, who never visited Tibet, relied on the translation by several Tibetan Buddhist, most importantly Lama Kazi Dawa-Samdup, to transpose and articulate the content of the Bardo Thödol. For an extensive commentary on the different editions of The Tibetan Book of the Dead, see Lopez (2011), who argued that the latter was a product of American Spiritualism rather than Tibetan Buddhism.
} 
pillars and contrasting forces to the European tradition of ars moriendi. The latter goes back to Ancient Greek and Roman traditions of 'good death', which were eventually translated into medieval and Christian notions of a pious death and were also taken up by modern medicine (Vovelle 1980; Carol 2004). In the second edition of 1949, Evans-Wentz highlights the main outcome of the Tibetan Book to the Dead: to teach the art of dying as an art of living. Interestingly, the editor contextualises the importance in relation to Western developments in medicine in the following way: 'here in America, every effort is apt to be made by a materialistically inclined medical science to postpone, and thereby to interfere with, the deathprocess' (Evans-Wentz 1949:xii). Evans-Wentz puts forward an argument that is then taken up by many anthropologists, sociologists, historians and psychologists, who, in the late 1950s, addressed strong criticism towards biomedical dealings with death (Feifel 1959; Kübler-Ross 1969; Noyes 1970). In the editor's view, the manual therefore affords an opportunity to the Western reader, who would be willing to follow the prayers of the Lamas, to dissipate 'that Darkness of ignorance' (Evans-Wentz 1949:xi). The latter (darkness of ignorance) was also attributed to medicine by EvansWentz. In the third version (1957), the inclusion of Jung's commentary (and a second foreword written by the Lama Anagarika Govinda), exemplifies that the previously emphasised taboo of death in medicine is replaced with a highlighting of the benefits of psychological insights. More particularly, the argument is that The Tibetan Book of the Dead helps to introduce Oriental philosophies into Western medicine and science. In this process, Jung plays a predominant role: "no greater honor could be shown by the Western World to this Tibetan treatise on the Science of Death and Rebirth than that shown by the most illustrious of the West's psychologists, Dr. Carl G. Jung' (Evans-Wentz 1957:vii). Here, Jung plays a significant role because he attests, with his credibility as a Western scientist and practitioner, the understanding and value of Oriental wisdom. Moreover, Evans-Wentz considers Jung as essential, because he offers a contrasting view to Freud. The editor considers the latter as omnipresent in American society and criticises him for his fear of metaphysics, which represents, in his view, the 'self-imposed limitations of Western science' (Evans-Wentz 1957:viii). Jung put forward in his commentary of the Bardo Tödöl that his approach was a contrasting view to Freud.

The introductory comments by Evans-Wentz make clear that a teaching about death, in 1957, is conceived not in terms of 'denial' or 'taboo' as most American writers would increasingly emphasise, and who rather referred to Freud (Feifel 1959; Farberow 1963), but in terms of a 
'journey' to be understood as an initiation into a spiritual realm unknown to the average Western reader. It is therefore no surprise that The Tibetan Book of the Dead version from 1957, comprehensive in terms of commentaries, would be read and re-edited at the height of the death and dying studies, in 1964. Timothy Leary, Ralph Metzner and Richard Alpert, at the height of the popular experimentation and consumption of psychotropic substances (most importantly LSD) - prominent protagonists in the countercultureturned the Bardo Tödöl into a psychedelic manual. In this book, they compare the first stage of the Bardo (Chikhai) to a 'period of ego-loss', the second to a 'period of hallucinations' (Chönyid), and finally the third to a 'period of re-entry' (Sidpa) (Leary \& al 1969). In the preface of this book, entitled The Psychedelic Experience: A Manual Based on the Tibetan Book of Dead (1969), the authors pay tribute to C. G. Jung. They highlight that 'he [Jung] recognized the rich meaning of the Eastern message' and knew how to react to 'that great Rorschach inkblot, the Tao Te Ching' (Leary \& al 1969:20). Similarly, they pay tribute to Evans-Wentz for his 'role of bridge and shuttle between Tibet and the West'. In addition, and interestingly, they highlight the important contribution of Evans-Wentz to the 'art of dying' (Leary \& al 1969:17). As I have shown, this aspect has been rather dismissed in the third edition (in contrast to the second edition). In 1957, only Sir John Woodruffe explicitly refers to this dimension in his preface entitled 'Science of Death'. Jung remains to a large extent rather focused on problems of consciousness than dying. In fact, Leary, Metzner and Alpert lamented that Jung was missing the meaning of The Tibetan Book of the Dead, since he wrote about the travels of the soul rather than the dying process. This aspect is not entirely accurate, as Jung followed the three stages in detail to make his psychological commentary explicit. But it is correct to say that Jung did not link the teachings of the Lama to a possible application in palliative care or the studies on death and dying. Jung's main purpose was, beyond connecting Eastern to Western philosophies, to find a therapeutic rationale and applicability for the initiation process described by the Bardo Tödöl. According to Jung's view, it is only with the workings of the unconscious that the third phase (Sidpa Bardo) (Jung 1957) can be opened. For instance, according to Jung, with the help of the therapist, birth instincts and prenatal elements can be addressed in this stage.

What is interesting about the commentaries made by Leary, Alpert and Metzner is that they do want to consider the manual for its applicability in the process of dying. The latter has to be understood in its psychological and consciousness-expanding dimension. In other words, they make it out to be an experiential and learning process, which can be mimicked and 
applied also in other forms that are not life-threatening for an organism, such as meditation, altered states of consciousness, and psychedelic experience. In the following, I will show how the consciousness-expanding studies also concerned academic psychiatry. There, Jung became an important source to build a theoretical model for the experience of nearly dying.

\section{DYING AND MYSTICAL CONSCIOUSNESS}

In 1944, Jung suffered a heart attack and experienced what he then claimed to be an experience 'after death': 'what happens after death is so unspeakably glorious that our imagination and our feelings do not suffice to form even an approximate conception of it' (Letters, Vol. 1, 343, cited by Yates 1999:6). In Memories, Dreams, Reflections (MDR), Jung recounts this experience. He describes how he traveled outside of the body, from Ceylon to the 'reddish-yellow desert of Arabia' and the Mediterranean, encountering on his way, a 'black block of stone' — like a meteorite_, where he visited a temple and saw a 'Hindu' seated in 'lotus posture' who was expecting him (Jung 1963:289-293). Along this journey, Jung encounters his treating physician, Dr. H., who appears in his 'primal form,' Basileus Kos. This encounter led Jung to believe that he was appearing himself in his 'primal form' (Jung:289-293). Subsequently, Jung's encounter with death was to have an important impact on his life. He addressed this issue on different occasions, notably in a letter addressed to Kristine Mann in 1945, in which he argued that this experience gave him a 'glimpse behind the veil' (Letters Vol. 1, 358-359, cited by Yates 1999:7).

Read by many psychologists, $M D R$ also attracted the attention of those who identified with neither Freud nor Jung in their practice. Russell Noyes $\mathrm{Jr}$ is one such example. The Midwestern psychiatrist, who practiced at University of IowaHospitals and Clinics, initially trained in psychoanalysisas almost all psychiatry residents did in the 1950s. He later turned towards descriptive psychiatry, in the lineage of Karl Jaspers and the British School of Psychiatry. But, at the beginning of the 1970s, in order to address the meaningfulness of dying experience and its potential impact for a psychiatric support to patients suffering from incurable illnesses, he turned to Jung. At the time, Noyes also wrote on subjects such as 'Grief', 'The Taboo of Suicide', 'Care and Management of the Dying' seeking to apply his psychiatric expertise to the increasingly growing field of palliative care.

In one of his articles, 'Dying and Mystical Consciousness', published in 1971, Noyes cites Jung's account of his near-death experience at length. Published in the first issue of the Journal of Thanatology, Noyes 
utilises Jung's personal account to explain the experience of nearly dying in terms of what he calls 'mystical consciousness'. Even though he draws mostly on examples from literature — from Poe's Descent into Maëlstrom to De Quincey's Confessions of an Opium-Eater and Tolstoy's The Death of Ivan Ilyich —-Noyes gives pride of place to Jung's account. He does so because of the 'real' nature of Jung's death-encounter and his scientific credibility. Noyes, for instance, considered Jung (together with Freud) as 'keen observers' of the 'subjective life' (Noyes 1971:26).

For Noyes, the important part about Jung's narrative was not so much the symbolic content or the archetypal images that the Swiss analyst revealed during his time-space travel. In contrast, he was rather interested in the 'noetic' and emotional qualities of the experience. The psychiatrist gives credit to this idea by citing the following extracts from Jung's account: 'it is impossible to convey the beauty and intensity of emotion during these visions ... I can describe the experience only as the ecstasy of a non-temporal state, in which present, past and future are one' (Noyes 1971:27). Elsewhere, Noyes adds another aspect to credit the 'noetic quality' of Jung's experience: 'I [Jung] had a feeling that everything was being sloughed away: everything I aimed at or wished for or thought, the whole phantasmagoria of earthy existence, fell away or was stripped from me — an extremely painful process' (Noyes 1971:26-27).

Noyes assembles Jung's citations to qualify 5 key aspects of a 'nearly dying' experience: 1) 'ineffability' (the difficulty for the person to talk about the experience), 2) 'transcendence of time' (as perceived by the person who was reportedly in a life-threatening danger situation), 3) 'a sense of truth' (revealed to the subject during the experience), 4) 'loss of control' (the person losing control over the events happening at the time), 5) 'emotional extremes' ('sensations of ecstasy, fear, depression') (Noyes 1971:27-28). In fact, with this qualification Noyes refers to William James' definition of a mystical state of consciousness that he initially defined in four elements. Noyes added to James' definition the fifth element, 'emotional extremes. ${ }^{6}$

Noyes, who was more a reader of James than of Jung (and who is here interpreting Jung through the lenses of James) ${ }^{7}$ highlights the historical connection between the two psychologists, because of their mutual interest in religion. It has been acknowledged by historians that Jung credited the impact that James's work had on his own practice. The

6 James developed his definition of a 'mystical state of consciousness' in his lectures on mysticism (XVI, XVII), published in The Varieties of Religious Experiences (1902).

${ }^{7}$ Interview with the author, May 2010, University of Iowa Hospitals and Clinics, Iowa City. 
Swiss analysist for instance highlighted in the Protocols of Memories, Dreams, Reflections that he 'esteemed James' openness and vision, which was particularly marked in his psychical research' and that he was 'very influenced by James' work on the psychology of religion' (Shamdasani 2003:58). For Noyes, Jung's compatibility with James was due to their mutual emphasis on the meaningfulness of a mystical experience for psychological investigation. This, in turn, allowed him to think further through the psychological mechanisms at stake in the dying experience (if happening suddenly, and in an unexpected way). In addition, their work allowed him to link the spiritual nature of the experience to a broader experimental practice, for instance self-experiments. James was a known self-experimenter and he attested to this in numerous ways, particularly in his comments on the experience with nitrous oxide (James 1882).

It is important to highlight here that James had an important revival in experimental psychology in the 1960s, when a renewed interest in mysticism was also proliferating. Practitioners, who experimented with psychotropic agents, Zen meditation, sleep, and more generally 'altered states of consciousness', regularly quoted James and discussed his contribution to recent discussions in philosophy, such as W. T. Stace's Mysticism and Philosophy, published in 1961 (Stace 1961; Deikman 1963; Fischer 1970; Kasamatsu and Hirai 1969). Some examined his definition of mystical consciousness in the form of a scale (questionnaire) to measure 'experimental mysticism', for instance Walter Pahnke and William Richards in their study on the effects of psilocybin on priests and laics (Pahnke and Richards 1966). During the 1960s, there was a broader interest in connecting clinical data to 'altered states of consciousness.' This expression was meant to convey a non-pathological perspective on experiences that traditionally would have been described in psychiatry in terms of disorders, and even mental illnesses (Ludwig 1966; Bowers and Freedman 1966). Charles Tart's edited book Altered States of Consciousness, first published in 1969, is a particularly good example. It shows how psychiatry, experimental psychology, dream studies, hypnosis, Zen Buddhism (in the laboratory) and psychedelic therapy could be used in a joint effort to promote non-pathological interpretations of mental life, as well as the valorisation of 'non-rational' states.

The omnipresence of James' work in experimental psychology, in particular the Varieties of Religious Experience, is indeed striking. James is also frequently cited, because he delivered in this book two pictorially remarkable examples of contrasting forms of mysticism: on the one hand Theresa of Avila (a person), on the other hand Samadhi (a state) (James 
1982:400-401, 408-413). In fact, this comparison (and illustration) of two mystical states was discussed by numerous practitioners at the time, and in particular those interested in establishing a theory of consciousness that builds phenomenological bridges between states of insanity, creativity and 'daily rational consciousness' (Fischer 1970). Interestingly, the remarkable representation of two emblematic or idealised forms of mysticism (West and East) was also present in Jung's effort to highlight the importance of Eastern philosophies for Western psychology. In his foreword to Daisetz Teitaro Suzuki's An Introduction to Zen Buddhism (1934), first published in German in 1939 and then translated into English in 1949, Jung refers to 'consciousness' and 'mysticism' to define the nature of Zen. There, he also uses two illustrations of Eastern and Western mysticism: Meister Eckhart and Satori. For Jung, a Zen-like consciousness can be linked to the idea of losing 'ego-boundaries': 'satori is interpreted and formulated as a break-through of a consciousness limited to the egoform in the form of the non-ego-like self' (Jung, in Suzuki 1964:14).

By the end of the 1960s, the inherent association was made between a Jamesian mysticism, Oriental philosophy and a psychology of transformation. The broad range of psy practitioners took, somewhat uncritically, James' understanding of mysticism and applied it to their own concern, which consisted either in understanding dying or altered states of consciousness. As I have shown, Jung's own account was used to formulate a psychiatric framework that allowed researchers to consider ineffable experience as clinically relevant. Furthermore, the experience of anticipating death was turned into a psychotherapeutic paradigm, as we will see in the following example of psychedelic therapy.

\section{PSYCHEDELIC ENCOUNTERS WITH DEATH}

In the mid-1960s, within the context of the development of psychedelic research and therapy with LSD, practitioners started to use the powerful psychotropic agent for the treatment of patients suffering from incurable or terminal illnesses. ${ }^{8}$ At that time, different approaches were practiced within psychadelic therapy, from behaviourist conceptions

${ }^{8}$ Since the late 1940s, LSD has been administered to patients suffering from mental illnesses (as well as to animals and 'healthy' subjects), initially to elucidate origins and semiology of mental illnesses, most importantly schizophrenia. A shift happened in the mid-1950s, when LSD most specifically was administrated for therapeutic purposes. For a history on the clinical and therapeutic use of psychotropic substances, see Dyck 2008; Tornay 2016. 
that aim to reach 'insightful responses' in patients suffering from problems of addition (Shagass \& al 1967) to psychodynamic therapies aiming for lower and repeated doses of psychothropic substances to treat a broad range of 'mental disorders'. Within the latter circles, the reception of Jung's work became a widely established practice. In Los Angeles, for example, Betty Eisner argued for a strong influence of LSD on the 'unconscious activity' (Eisner 1963). She developed her work in dialogue with Ronald Sandison, a Jungian UK therapist who installed an LSDclinic at Powick Hospital and coined the term 'psycholytic therapy'. The latter refers to a specific agency (of the substance) on the unconscious and explores in the psychotherapeutic treatment creative processes. In Germany, Hans Leuner was equally influential in disseminating psycholytic therapy. He used materials depicted by his patients to whom he administered LSD to provoke a 'symbolic death and rebirth' (Leuner 1963:68). Leuner furthermore considered the 'constituent part of hallucinatory archetypal symbols', as by psychotropic drugs, in line with C. G. Jung's conception of the collective unconscious (Leuner 1963:68). In the history of psychedelic therapy's application in clinical palliation, Jung's legacy served practitioners to lay out a theory for chemically-induced 'human encounters with death' (Grof/Halifax 1977). The most striking example of this procedure is Stanislav Grof. An emigrated Czechoslovakian psychiatrist, Grof became part of the Spring Grove Experiment in Maryland (1965-69), a seminal clinical project that involved numerous LSD sessions. Later, in the beginning of the 1970s, he worked at the Maryland Psychiatric Research Centre, where he built together with his collaborators sessions specifically dedicated to the treatment of patients suffering from incurable or terminal illnesses. Dealing with patients who were suffering from 'aging, disease, physical pain and agony', Grof's goal was to apply psychedelic therapy (using LSD) to address the 'critical aspects of human existence' that often accompany the 'deep realization of the frailty and impermanence' of one's 'biological existence' (Grof 1973:25). He summarised these findings in several books, among them Realms of the Human Unconscious: Observations from LSD Research (1975); The Human Encounter with Death, cowritten with Joan Halifax (1977); and LSD Psychotherapy (1980).

Applying a procedure that is based both on Jung (the idea of ancestral memories and the collective unconscious) and Rankian theory of birth (the idea that pre-birth experiences influence the mental state of an individual), Grof and his co-workers set up a therapeutic procedure that aimed to explore mental material through visualisation processes. His goal was to 
work through what he characterised as 'systems of condensed experience' (COEX) (Grof 1975:101; 1973). In other words, LSD helped the client or patient to reach different stages of the experience and layers of the unconscious. Although Grof argued that the results of psychedelic therapy depend on set and setting, the therapist's approach and the individual's constitution, in principle, the following stages are reached: 1) 'abstract and aesthetic experience', 2), 'psychodynamic experience', 3) 'perinatal experience', 4) 'transpersonal experience' (Grof and Halifax 1977:40). The four different categorisations of an experience reached with the assistance of LSD reflect other writings at the time. For example, in Varieties of Psychedelic Experience: The Classic Guide to the Effects of LSD on the Human Psyche, a book written in 1966 by R.E.L. Masters and Jean Houston, the authors distinguish between four different layers, or levels, to be reached within a LSD session; 'the sensory', the 'recollective-analytic', the 'symbolic' and the 'integral or mystical' (Kripal 2007:256). Masters and Houston's reference to James' work on the psychology of religion, here in terms of experimental psychedelic varieties of experience, shows again to what extent James was relevant to the consciousness-expanding and experimental psychology practitioners at the time. James' work allowed practitioners, for instance, to talk about 'non-rational experiences' and to highlight their benefit for mental health or personal growth.

Grof utilised LSD to trigger, most importantly, what he called a 'perinatal experience.' This literally means to provoke a state of neardeath (a sensation of extreme fear), followed by a symbolic re-birth. In an LSD-assisted therapy imagined and realised by Grof and his coworkers, the therapist guides the patient through different stages of visualisation, of often threatening and traumatic experiences that lead back to childhood. For Grof, the 'shocking emotional and physical encounter with the phenomenon of death' is the 'opening up of spiritual and religious dimensions that appear to be an intrinsic part of the human personality' (Grof 1973:25). He adds, furthermore, that these dimensions are independent of the 'individual's cultural and religious background and programming' (Grof 1973:25). With the latter, Grof brings into play Jung, arguing that archetypal images of the 'Great Mother' and 'Terrible Mother' characterise some of the perinatal matrices (Kripal 2007:256). ${ }^{9}$ Grof, in line with Rank, considers death and birth on a continuum: 'the similarity

\footnotetext{
9 It is important to highlight here that Grof was not only inspired by Jung's work, but also drew on Rank and Freud. His work also has to be contextualised with regards to Grofs' reinterpretation of tantrism, and psychological theories of sexuality/eroticism and death. See Kripal 2007.
} 
between birth and death — the starting realisation that the beginning of life is the same as its end — is the major philosophical issue that accompanies the perinatal experiences' (Grof 1973:25). To facilitate a guidance through this intermediate state, which Grof and Halifax call the 'psychedelic metamorphosis of dying', four different 'basic perinatal matrices' (BPM I-IV) are ideally reached. These can be explained as stages through which the individual evolves, following a symbolic logic that mimics the life of a fetus in the womb until its delivery through the birth canal (Kripal 2007). The four different matrices are: 'primal union with mother'; 'antagonism with mother'; 'synergism with mother'; 'separation from mother'. During the therapy, the matrices are reached with the guidance of the therapist. Patients produce visual materials after the therapy, mostly drawings. Grof summarises and explains their meaning, as following a death-rebirth experience. For instance, in two illustrations made by the same patient, Grof transcribes the patient's experience and interprets the drawings as: a 'suffocation and dyspnea' (the patient was reliving a rebirth experience), or the representation of the 'horrors of birth trauma' (Grof 1975:98).

Grof's LSD-assisted therapy demonstrates an important aspect of death and dying studies, relevant for the intellectual history of psychological disciplines, in the period under investigation: it laid the foundations for a theoretical framework for transpersonal psychology (Grof 1973). Grof argues in his work that traditional psychotherapies generally tended to exclude the birth trauma. In his view, to conduct a 'reliving' of this trauma would allow to liberate some of the generally avoided materials in therapy (spiritual, religious, mythological). With this, he aims to link 'individual psychology with transpersonal psychology', and 'psychology with religion' (Grof 1975:99). Grof, a therapist, transposes thus a Jungian definition of what exceeds the personal (überpersönlich, the equivalent of collective unconscious) into a new paradigm: the transpersonal. He utilises chemically-induced altered experiences and their ability to trigger sensations of Urangst in order to establish a new paradigm, along with other practitioners equally interested in spiritual aspects. Together with Abraham Maslow and James Fadiman, Grof was one of the key players in establishing the Association of Transpersonal Psychology. To come back to the initial comments made on humanistic psychology, it is important to highlight that when transpersonal psychology first started to be promoted in the early 1970s as a professional organisation, it still largely passed through a validation by humanistic psychology. In fact, several psychedelic studies that were conducted within a transpersonal paradigm, or referring to the ideas promoted by transpersonal psychology, included references to 
humanistic psychology, and notions such as 'peak experience' and 'positive psychedelic contents' (Pahnke and al 1970). When Grof first presented the empirical data of his LSD therapy in accordance with a transpersonal paradigm, he was doing it at the Annual Conference of the Association for Humanistic Psychology (in 1972, in Squaw Valley). On the other hand, and to come back to the previous section of the text, 'consciousness' at the time was debated (in psychology) at the intersection of humanistic psychology, theory of creativity and psychedelic exploration. A major conference, The Council Grove Conference on Altered States of Consciousness, organised in 1969 by the Research Department of the Menninger Foundation and the American Association of Humanistic Psychology, illustrates this best. It brought together some of the key protagonists to discuss chemically-altered consciousness within the context of human growth and Jamesian psychology of religion: Jean Houston, Stanley Krippner, Robert Masters, Charles Tart, Walter Pahnke, James Fadiman, Carlos Castaneda, Abraham Maslow, Sanford Unger, Joe Kamiya, Alexander Shulgin, and of course, Stanislav Grof. Grof's psychedelic encounters with death valued a syncretic approach towards the understanding of dying. The use of LSD for the 'human encounter with death', furthermore, allowed the psyche to be resituated outside of the medical realm. This highlights a shift towards transpersonal psychology, where the collective unconscious and archetypal images are valued. The important aspect of Grof's work and the psychedelic sessions of death-mimicking, was that the experience of dying was associated with a separation from one's idea of selfhood. The latter would eventually lead, in this perspective, to profound psychic transformation. The symbolic value of this process was furthermore accentuated in the context of suicidology, research on suicidal behaviors in the early 1970s. There, a Jungian approach served not only to qualify the 'dying process' but also to structure ways in which the latter could contribute to the clinical practice of treating depression.

\section{SUICIDE SURVIVORS AND TRANSFORMED ILLNESSES}

The American Association of Suicidology, an association created by psychiatrists and suicide prevention specialists in 1967 in Los Angeles, introduced a major shift in the study of suicide. Rather than preventing suicide (with physical barriers and other measures), the idea behind it was to study behaviors related to suicide, such as the motivations underlying an individual's attempt to commit suicide, and how they relate to cultural 
beliefs, and personality. The works of Edwin S. Shneidman and Norman Farberow are referential in this regard. One example that implemented suicide research more specifically was a study conducted on the survivors who attempted suicide in the Bay area in the early 1970s. Two researchers, Richard Seiden and David Rosen, were involved in the study, which consisted of interviewing 6 of the 8 survivors who attempted and survived a suicide at the Golden Gate Bridge or San Francisco-Oakland Bay Bridge. Rosen, a Jungian analyst, was appointed chief resident in 1974 at the Langley-Porter Neuropsychiatric Institute, University of California Medical Center in San Francisco. ${ }^{10}$ In a study published in 1975 (Rosen 1975), Rosen describes the sudden encounter with death during experiences of a fall or jump as 'mystical states of consciousness characterized by loss of the conventional senses of time, space and self' (Rosen 1975:293). Referring to Noyes, and hence the refashioning of Jamesian mysticism, Rosen also argued that most of the survivors, 'during or after their jumps', 'experienced a sense of oneness or unity with other human beings and the entire universe' (Rosen 1975:293). Here, he more specifically refers to Grof to qualify the survivors' experiences as 'death-rebirth experiences', because they represent 'both an ego-death (a feeling of total annihilation) and a rebirth (with feelings of love and salvation') (Rosen 1975:293).

This study shows that there is an evolution (or shift) from a concern for thanatology (or, to say the least, suicide prevention) to a clinical and therapeutic application of the interpreted empirical data. For instance, Rosen applied his empirical research, widely disseminated at the time in the popular press, as was the study of near-death experiences, into his analytic work: the treatment of patients who suffer from depression. In a book first published in 1993, Transforming Depression: Healing the Soul Through Creativity (reedited in 2002 by the publisher Jung on the Hudson Book Series), Rosen implements the concept of egocide as a tool to generate the creative potential of his patients. This process was thought to lead to substantial transformation in the perception of the self, characterised by Rosen as 'the archetype of wholeness and eternity' (Rosen 2002:97). Using techniques from within a Jungian tradition, such as 'active imagination', the therapist guides his patients through a visualizing process, in which they imagine their own annihilation (of self). This process is characterized as cathartic and impactful for the healing of a person's suffering. Drawings and paintings produced by the patients play a major part in this symbolic journey. Rosen calls them 'healing images', and qualifies their meaning

${ }^{10}$ Created in 1941, the Langley-Porter was an important institution for the academic implementation of analytic psychology in the United States (Kirsch 2000). 
in terms of archetypes, because they tend to evoke (and therefore represent, in a clinician's view) both positive and negative possibilities. Rosen gives the example of the 'mother', the 'shadow' and frequently refers to the uroboros (the image of the snake eating its own tail) to characterise the experience of no beginning and no end (Rosen 2002: 87).

In addition to promoting Jung's oeuvre in California, Rosen was later also involved in invigorating the relationship with Chinese Jung scholars and analysts. ${ }^{11}$ This example illustrates how, within a context of suicide prevention, a study on the psychological impact of the experience (of jumping off the bridge and having a potential near-death experience) on the person became important. This, in turn, allowed the creative potential to be introduced as an essential element in the psychotherapeutic treatment of depression. The strong emphasis on Jung (personal-collective shadow, archetypal mother, the reunion with anima) and Eastern philosophies, shows a different type and itinerary of the Jungian legacy. The latter was not directly articulated (in the 1970s) through The Tibetan Book of the Dead or Jung's $M D R$ (although Rosen claimed later that Jung's $M D R$ had a tremendous impact on his practice), but rather through a reading of Noyes and Grof. For instance, Rosen read the writings by Russell Noyes on the 'experience of dying' (Noyes 1972:174), a study on the accounts of people who have nearly died from sudden accidental causes, and in which Noyes postulated a three-stage scheme of dying: 1) 'resistance' 2) 'life review', 3 ) 'transcendence' (Noyes 1972). Rosen completed Noyes' interpretation, arguing that those who attempted to commit suicide prepared for the idea of death and therefore did not experience all phenomena that Noyes described ('life or panoramic memory,' for example, was missing in Rosen's view). Rosen further argued that, because of the preparative aspect, suicide survivors would generally tend to have an even stronger personal transformation after a failed attempt. Some of the survivors, for instance, claimed that they found renewed strength in religious beliefs (Rosen 1975).

In this trajectory from suicide studies to a therapy for patients suffering from depression we can also discover the value of symbolic interpretations of a suicide attempt and the subsequent introduction of these insights into therapy. The visual illustrations (drawings from patients) that Rosen reproduces in his book (Rosen 2002) evoke this specific encounter between

\footnotetext{
11 Along with other analysts, John Beebe, Stan Marlan and Ruth Ledergerber, Rosen travelled to Professor Heyong Shen's first International Conference of Jungian Psychology and Chinese Culture at Guangzhou University in December 1998 (Kirsch 2000: 221). Rosen wrote also a book, re-interpreting Jung's life in terms of Taoist principles (The Tao of Jung: The Way of Integrity, 1996).
} 
Jungian archetypes and the uncovering of unconscious material in terms of death-and-rebirth experiences, as they were emphasised in the 'psychedelic metamorphosis of dying' by Grof and Halifax (Grof 1975). The broader context out of which the archetype-personality affiliation evolved is the development of studies that approach suicide in a de-pathologising perspective. James Hilllman, for instance, highlighted the individual 'death experience' as transformative in his book Suicide and the Soul, which laid the groundwork for the establishment of his archetypal psychotherapy (Hillman 1976:56). ${ }^{12}$ On the other hand, the image-centered therapy and the emphasis on symbolic journey refers also to, yet not in a direct way, Gestalt therapy. There, the 'hot chair sessions', as practiced at Esalen, were conceived as a place where 'old' and 'new' versions of self were debated, 'killed', 'eaten' or replaced (Perls 1992). In Rosen's image-based practice ('healing images') it is possible to find similar evocations, such as: 'giving birth to death shit'; 'giving birth to myself', and, more colorful, 'a Symbol of the self-soul emerged out of the Gestapo energy of the destructive shadow and was a hopeful image for [the patient]' (Rosen 2002:188).

\section{LEGACIES}

What is the legacy of Grof, Rosen's suicide work, Noyes' mystical consciousness and the countercultural re-reading of The Tibetan Book of Dead? What are the ways in which Jung's work is still manifested in studies concerned with death and dying?

Scholarly studies on near-death experiences (NDE) are one way to answer this question. Studies on NDE flourished since the early 1970s, although the popular success of this concept is generally attributed to Raymond Moody's Life after Life (1975). The latter set the framework for the general perception and discussion of this subject: it was about 'survivors' of 'death' and not about testimonies on an experience of 'nearly dying'. In other words, it was about the spiritual underpinnings delivered mostly by patients to the medical practitioner (cardiologists who reported either patients' experiences related to cardio-vascular diseases or emergency care treatments). This shift of perception, away from a descriptive approach inspired by the humanities towards questions of after-life (survival of the soul after bodily death), included

\footnotetext{
12 Suicide was also among the key topics to be addressed by thanatologists to discuss the 'taboo of death' in medicine and psychiatry, or more generally, 'taboo topics' in society (Farberow 1963).
} 
more overtly questions of paranormal phenomena (Martinovic 2017). In these discussions, starting predominantly in the late 1970s (and that reactivate the long-standing tradition of psychical research), the reported narratives of survivors frequently cite the 'tunnel experience', travelling through an otherworldly light, or encounters with deceased persons. In this emerging tradition of NDE studies conducted by parapsychologists, Jung's legacy again came into play. Jung's ideas about synchronicity, his interest in paranormal phenomena and immortality were emphasised. For example, in an effort to produce a scholarly work on NDE studies, Jenny Yates authored The Near-Death Experience: A Reader (1996). This was followed by an edited book on Jung and Immortality (Yates 1998).

Another example is Bruce Greyson and his research team in Charlottesville, Virginia. A distinguished professor of psychiatry, Greyson is also the director of the Division of Perceptual Studies at the University of Virginia, a place with a long-standing tradition in parapsychology. ${ }^{13}$ There, researchers connected a whole range of research subjects to NDE studies-telepathy, precognition and other psi phenomena ${ }^{14}$. One of his coworkers, Michael Grosso, a philosopher, wrote an article entitled 'Jung, Parapsychology, and the Near-Death Experience. Toward a Transpersonal Paradigm' (Grosso 1982). The article was published in Anabiosis (created in 1982 by the International Association for Near-Death Studies, later renamed Journal of NDE Studies). In this lengthy text, Grosso considers NDE as evidence for the activation of a unique archetype that the author calls Archetype of death and enlightenment (ADE). The function of this archetype is the 'process of enlightenment, a passage toward greater consciousness of the Self' (Grosso 1982:15). Moreover, Grosso presents $\mathrm{ADE}$ as a contributing force in the individuation process. He then goes on to discuss the variety of near-death imageries and their meanings, drawing on symbols from creation myths (Rig Veda, Old Testament) to allegories (Plato's Cave) and modern philosophy. Ultimately, Grosso's goal is to establish, with the help of ADE (and via Jung), a transpersonal paradigm. To read Grosso allows us therefore to reach a form of Jung's reception that

13 The Institute (DOPS) was founded in 1967 by Ian Stevenson, psychiatrist who brought into academia the empirical study of phenomena of reincarnation. Thanks to an important financial contribution that Chester Carlson, inventor of xerography, left after his death in 1968, the Institute was able to develop its activities and studies into parapsychology.

14 This effort goes back to the early days (1980s), when NDE research was mostly conducted by transpersonal psychologists, and parapsychologists. In the publications edited by The Journal of Near-Death Studies, mentions of 'soul' or 'after-life' are frequently discussed. But the 'archetype' also re-emerged in this literature. 
goes all the way back to The Tibetan Book of the Dead, which the author also discusses. Moreover, it enables us to discover how Jung's relevance with regards to death and dying shifted from a previously focused interest in psychedelic science to questions rather focusing on immortality and psi phenomena. Almost two decades later, Grosso would co-edit with his colleagues from Charlottesville the book Irreducible Mind: Toward a Psychology of the $21^{\text {st }}$ Century (2009). The book aimed to articulate NDEs in a non-pathological perspective. The authors also attempted to answer the neuroscientific investigations into the phenomenon of NDEs, which described these in terms of a brain dysfunction. In the book, the authors attribute an important role to the writings of F. W. H. Myers and William James.

\section{CONCLUSION}

This article took the dissemination of Jung's work in the 1960-80s as a main impetus to examine ways in which death and dying studies were shaped by the reception of Jung's work. If Jung has generally been credited for his impact on a renewed interest in spirituality in psychotherapy, the article has located the debate in a broader discussion on Jung's equally influential role in defining a psychological approach to death, and using near-death as a psychotherapeutic model. The four examples discussed have shown that Jung's reception was shaped around different key aspects: ineffability of the experience (difficulty to talk about it), which allowed Jung's experiences to be compared to James' notion of mysticism; furthermore, collective unconscious and archetypal images as determinant factors of self-transformation to make the process of anticipating death clinically relevant; the preparation for death conceived as a process of loosening ego-boundaries, comparable to Oriental spiritual traditions (egocide).

Psychologists brought into play concepts elaborated by James and Jung, sometimes without going into depth into their works. Rather, the psy practitioners were interested in the application of a psychology of religion to death and dying studies, thanatology (what does death mean in a society marked by enormous biomedical progress?), and more generally altered states of consciousness (valuing non-rational states). As I have shown, the James-Jung association was particularly important in experimental psychology, where studies on ASC, meditation, sleep and psychoactive drugs were conducted to gain insights into mental processes and to articulate a theory of consciousness. The renewed interest in Tibetan Buddhism furthered this association. 
That these emergent practices in the field of death and dying studies consistently altered the meaning of both Jung and Oriental philosophies does not question the relevance the latter had and continue to have within a particular field, especially in therapy. A historical investigation into an intellectual history of Jung's reception or legacy, as I have shown it here, therefore cannot separate psychology from cultures: scholarly, clinical, therapeutic, experimental, and linguistic.

To investigate Jung's reception in death and dying studies gives us not only an insight into the 'extreme plasticity' of Jung's concepts (Shamdasani 1999:54), as they were adopted and reformulated in the decades that followed his death. It also allows us to rethink the wider cultural range of psychotherapy. Psychology has shaped notions of death, not only since Jung, but also before (think of Freud's influential considerations on death published after World War I), establishing a link between individual psychology and collective psychology. Dying in the 1910s or 1930s did not mean the same thing as in the 1960 s or nowadays (Bromberg \& Schilder 1933; Bromberg 1982:89). Neither did the discussion about death, incurable illnesses and individual suffering matter the same way in the past as in the present. Yet, the specifically 1960s-definition of death as being both a psychological and potentially spiritual experience, reactivated via Jung (and James!), continues to shape today's conceptions of dying. The latter is seen as a potentially transformative experience, as well as a meaningful (imaginative) process. This has for example been recently reactivated by studies using psilocybin to treat depression, which shows once again how art of dying and psychotherapy continue to shape the present with the past. These studies frequently cite mystical states of consciousness (often via Pahnke and Richards) and use the category to evaluate the meaningfulness of the psychopharmacological experience of cancer patients (Ross \& al 2016). Thus, in these recent clinical trials, one can find a continuous articulation which states that 'mystical psychedelia' would somehow allow the individual not only to cope with death, but ultimately also with life.

With this in mind, the history of Jung's reception in the United States has to be highlighted once again as a consequence of the powerful mid-twentieth century connection between (a Western interpretation of) Tibetan Buddhism and humanistic psychology: the idea that death is a transformative element in one's life, but also an event that extends the imagination of what a self can do. To reach one's full potential (of the self), psy practitioners promote, now and then, therapy, creative activities, or chemical substances to expand the possibilities of the mind. One can therefore question whether these recent suggestions do not ultimately 
express 'coping strategies' (in clinical practice) to deal with the more general decline of spirituality, which medicine and psychology have sought to compensate progressively since the mid-twentieth century in different ways: clinical pastoral care, grief counselling, palliative care.

\section{University College London martinovic.j@gmail.com}

\section{REFERENCES}

Allport, Gordon W. 1955. Becoming. Basic Considerations for a Psychology of Personality. New Haven: Yale University.

Bromberg, Walter and Schilder, Paul. 1933. 'Death and Dying. A Comparative Perspective of the Attitudes and Mental Reactions Toward Death and Dying'. Psychoanalytic Review 20: 133-185.

Bromberg, Walter. 1982. Psychiatry Between the Wars, 1918-1945. A Recollection. Westport \& London: Greenport.

Bowers, Malcom and Freedman, Daniel. 1966. 'Psychedelic Experience in Acute Psychoses'. Archives of General Psychiatry 15 (3): 240-248.

Burston, Daniel. 1991. The Legacy of Erich Fromm. Cambridge: Harvard University Press.

Carol, Anne. 2004. Les médecins et la mort. Paris: Flammarion.

Charon, Rita and Williams, Peter. 1995. 'Introduction to Humanities and Medical Education.' Academic Medicine 70: 758-760.

Cohen-Cole, Jamie. 2014. Open Mind. Cold War Politics and the Sciences of Human Nature. Chicago: The University of Chicago Press.

Deikman, Arthur. 1963. 'Experimental mysticism'. Journal of Nervous and Mental Disease 176: 329-343.

Dyck, Erika. 2008. LSD Psychiatry: LSD from Clinic to Campus. Baltimore: John Hopkins Universisty

Eisner, Betty. 1963. 'The Influence of LSD on Unconscious Activity'. In Roonald Sandison and Alexander Walk (eds.). Hallucinogenic Drugs and the Therapeutic Use. London: H. K. Lewis.

Evans-Wentz, Walter. 1949. The Tibetan Book of the Dead. Or, The AfterDeath Experiences on the Bardo Plane, according to Lama Kazi Dawa- 
Samdup's English Rendering. London: Oxford University Press.

- 1957. The Tibetan Book of the Dead. Or, The After-Death Experiences on the Bardo Plane, according to Lama Kazi DawaSamdup's English Rendering. London: Oxford University Press.

Farberow, Norman L. (ed.). 1963. Taboo Topics. New York: Atherton Press.

Feifel, Herman. 1959. The Meaning of Death. New York: McGraw-Hill.

Fischer, Roland. 1970. 'Prediction and Measurement of PerceptualBehavioral Change in Drug-Induced Hallucinations'. In Wolfram Keup (ed.). Origin and Mechanisms of Hallucination. New York, London: Plenum Press.

Fromm, Erich. 1955. The Sane Society. New York: Rinehart.

Gardner, Murphy. 1959. 'Discussion'. In Herman Feifel (ed.). The Meaning of Death. New York: McGraw-Hill: 317-340.

Grof, Stanislav. 1973. 'Theoretical and Empirical Basis of Transpersonal Psychology and Psychotherapy: Observations from LSD Research'. The Journal of Transpersonal Psychology 5: 15-30.

- 1980. Beyond Death: The Gates of Consciousness. New York: Thames and Hudson.

- 1975. Realms of the Human Unconscious. New York: The Viking Press.

Grof, Stanislav and Halifax, Joan. 1977. The Human Encounter with Death. New York: A. Dutton.

Grosso, Michael. 1982. 'Jung, Parapsychology, and the Near-Death Experience: Toward a Transpersonal Paradigm'. Anabiosis, The Journal of Near-Death Studies: 3-38.

Hillman, James. 1976 [1964]. Suicide and the Soul. Irving: Spring Publications.

James, William. 1982 [1902]. The Varieties of Religious Experience. New York: Penguin Classics. 1882. 'On some hegelisms.' Mind 7 (26): 186-208.

Jung, Carl Gustav / Jaffé, Aniela. [1962]. Memories, Dreams, Reflections, tr. Clara and Richard Winston. New York:Vintage Books, 1989.

1957. 'Psychological Commentary on the Tibetan Book of the 
Dead.' In Walter Evans-Wentz (ed.). The Tibetan Book of the Dead. Or, The After-Death Experiences on the Bardo Plane, according to Lama Kazi Dawa-Samdup's English Rendering London: Oxford University Press.

. 1991. Psychology of the Unconscious. Princeton: Princeton University Press. . 2009. The Red Book. Liber Novus. London: W. W. Norton. Edited and Introduced by Sonu Shamdasani, Translated by Mark Kyburz, John Peck, and Sonu Shamdasani. New York / London: W. W. Norton \& Company

Kasamatsu, Akira and Hirai, Tomio. 1969 [1966]. 'An Electroencepholographic Study on the Zen Meditation (Zazen)'. In Charles Tart (ed.). Altered States of Consciousness. New York: John Wiley \& Sons.

Kirsch, Thomas B. 2000. The Jungians. A comparative and historical perspective. London \& Philadelphia: Routledge.

Kripal, Jeffrey J. 2007. Esalen. American and the Religion of No Religion. Chicago \& London: The University of Chicago Press.

Kübler-Ross, Elisabeth. 1969. Death and Dying. New York: MacMillan.

Leary, Timothy; Metzner, Ralph and Alpert, Richard. 1969 [1964]. The Psychedelic Experience: A Manual Based on the Tibetan Book of Dead. New York: University Books.

Leuner, Hans. 1963. 'Psychotherapy with Hallucinogens.' In Richard Crockett, R. A. Sandison and Alexander Walk (eds.). Hallucinogenic Drugs and their Psychotherapeutic Use. London: H. K. Lewis.

Lopez, Donald S. 2011. The Tibetan Book of the Dead: A Biography. Princeton: Princeton University Press.

Ludwig, Arnold. 1966. 'Altered States of Consciousness.' Archives of General Psychiatry 15: 225-234.

Martinovic, Jelena. 2017. Mort imminente. Genèse d'un phénomène scientifique et culturel. Geneva: MetisPresses.

McGuire, William. 1995. 'Firm Affinities. Jung's relations with Britain and the United States.' Journal of Analytical Psychology 40: 301-326.

Moustakas, Clark E. 1956. Self: Exploration in Personal Growth. New York: Harper \& Row. 
Maslow, Abraham. 1976 [1964]. Religions, Values, and PeakExperiences. London: Penguin Books.

Noyes, Russel Jr. 1970. 'Montaigne on Death.' Omega 1: 311-323.

- 1971. 'Dying and Mystical Consciousness.' The Journal of Thanatology. The Scientific Study of Death 1: 24-41.

- 1971. 'Dying and Mystical Consciousness.' Thanatology: The Scientific Study of Death 1: 25-41.

—. 1972. 'The Experience of Dying.' Psychiatry 35: 174-184.

Noyes, Russell and Roy Kletti. 1977. 'Panoramic Memory: A Response to the Threat of Death.'. Omega 8: 181-193.

Pahnke, Walter and Richards, William. 1966. 'Implications of LSD and experimental mysticism.' Journal of Religion and Health 5: 175-208.

Pahnke, Walter; Kurland, Albert A.; Unger, Sanford; Savage, Charles; Wolf, Sidney; Goodman, Louis E. 1970. 'Psychedelic Therapy (Utilizing LSD) with Cancer Patients'. Journal of Psychedelic Drugs 3: 63-75.

Perls, Fritz S. Gestalt Verbatim. 1992 [1969]. Highland: Gestalt Jornal.

Perry, John Weir. 1953. The Self in Psychotic Process. Its Symbolization in Schizophrenia. Berkeley and Los Angeles: University of California Press.

Rosen, David. 2002. Transforming Depression. Healing the Soul Through Creativity. York Beach ME: Nicolas-Hays.

1975. 'Suicide Survivors: A Follow-up Study of Persons Who Survived Jumping from the Golden Gate and San Francisco Oakland Bay Bridges.' The Western Journal of Medicine 122: 289-294.

Shagass, Charles and Robert Bittle. 1967. 'Therapeutic Effects of LSD: A Follow-Up Study.' The Journal of Mental and Nervous Disease 144 (6): 471-477.

Shamdasani, Sonu. 1998. Cult Fictions: C. G. Jung and the Founding of Analytical Psychology. London, New York: Routledge.

— 1999. 'Is analytical psychology a religion? In statu nascendi'. Journal of Analytical Psychology 44: 539-545.

- 2003. The Making of Modern Psychology. The Dream of a Science. Cambridge: Cambridge University Press.

—. 2008. 'The Boundless Expanse: Jung's Reflections on 
Death and Life'. Quadrant 38 (1): 9-332.

- 2017. 'Questioning the Unconscious.' Annals of the New York Academy of Sciences 1406: 86-69.

. 2012. C. G. Jung: A Biography in Books. London/New York: Norton.

Smith, Roger. 1997. A Fontana history of the human sciences. London: Fontana.

Stace, Walter T. 1961. Mysticism and Philosophy. London: MacMillan.

Suzuki, Daisetz Teitaro. 1964 [1934]. Introduction into Zen Buddhismus. New York: Grove Press.

Tart, Charles. 1968. Altered States of Consciousness. New York: John Wiley \& Sons.

Taylor, Eugene. 1998. 'Jung before Freud, not Freud before Jung: the reception of Jung's work in American psychoanalytic circles between 1904 and 1909'. Journal of Analytical Psychology 43: 97-114.

1986. 'C. G. Jung and the Boston psychopathologists'. In Daniel Lathrop, Mark Stern and Karen Gibson (eds.). Carl Jung and Soul Psychology. New York: Haworth Press.

Tornay, Magalay. 2016. Zugriffe auf das Ich. Psychoaktive Stoffe und Personenkonzepte in der Schweiz, 1945-80. Tübingen: Mohr Siebeck.

Vovelle, Michel. 1980. 'Rediscovery of Death since 1960'. The Annals of the American Academy of Political and Social Sciences 447: 89-99.

Wulff,David. 1991.PsychologyofReligion: Classic \& ContemporaryViews. New York: John Wiley \& Sons.

Yates, Jenny. 1999. Encountering Jung. Jung on Death and Immortality. Princeton: Princeton University Press. 